\title{
Transactional leadership, supply chain quality and business performance in the fast-moving consumer goods industry
}

\begin{tabular}{|c|c|}
\hline \multicolumn{2}{|c|}{$\begin{array}{l}\text { Authors: } \\
\text { Ettiene Jacobs }{ }^{1} \text { (D) } \\
\text { Chengedzai Mafini }^{2} \text { (D) }\end{array}$} \\
\hline \multicolumn{2}{|c|}{$\begin{array}{l}\text { Affiliations: } \\
{ }^{1} \text { Graduate School of Business } \\
\text { Leadership, University of } \\
\text { South Africa, Midrand, } \\
\text { Johannesburg, South Africa }\end{array}$} \\
\hline \multicolumn{2}{|c|}{$\begin{array}{l}{ }^{2} \text { Department of Logistics, } \\
\text { Faculty of Management } \\
\text { Sciences, Vaal University of } \\
\text { Technology, Vanderbijlpark, } \\
\text { South Africa }\end{array}$} \\
\hline \multicolumn{2}{|c|}{$\begin{array}{l}\text { Corresponding author: } \\
\text { Chengedzai Mafini, } \\
\text { chengedzaim@vut.ac.za }\end{array}$} \\
\hline \multicolumn{2}{|c|}{$\begin{array}{l}\text { Dates: } \\
\text { Received: } 29 \text { Jan. } 2019 \\
\text { Accepted: } 11 \text { Mar. } 2019 \\
\text { Published: } 06 \text { May } 2019\end{array}$} \\
\hline \multicolumn{2}{|c|}{$\begin{array}{l}\text { How to cite this article: } \\
\text { Jacobs, E. \& Mafini, C., 2019, } \\
\text { 'Transactional leadership, } \\
\text { supply chain quality and } \\
\text { business performance in } \\
\text { the fast-moving consumer } \\
\text { goods industry', Journal of } \\
\text { Transport and Supply Chain } \\
\text { Management 13(0), a442. } \\
\text { https://doi.org/10.4102/ } \\
\text { jtscm.v13i0.442 }\end{array}$} \\
\hline \multicolumn{2}{|c|}{$\begin{array}{l}\text { Copyright: } \\
\text { (c) 2019. The Authors } \\
\text { Licensee: AOSIS. This } \\
\text { is licensed under the } \\
\text { Creative Commons } \\
\text { Attribution License. }\end{array}$} \\
\hline \multicolumn{2}{|l|}{ Read online: } \\
\hline apsin: & $\begin{array}{l}\text { Scan this QR } \\
\text { code with your } \\
\text { smartphone or } \\
\text { mobile device } \\
\text { to read online. }\end{array}$ \\
\hline
\end{tabular}

Background: Literature provides evidence of how the fast-moving consumer goods (FMCG) industry has become a strategically important contributor to economic growth and competitiveness globally. However, this industry in South Africa faces consistent challenges that demand immediate attention and solutions. A potential area of intervention relates to how leadership practices can be applied to improve the quality and performance of FMCG supply chains in South Africa.

Objectives: This study examined the link between transactional leadership, supply chain quality (SCQ) and business performance in the FMCG industry within Gauteng province, South Africa.

Method: The research followed a quantitative approach in which data were collected through a survey targeting managers and professional employees of the FMCG industry in the Gauteng province. The collected data were analysed through descriptive statistics, exploratory factor analysis, Pearson correlations and regression analysis.

Results: Two transactional leadership styles, namely contingent reward and management by expectation (active), were statistically significant in influencing SCQ. Passive-avoidant leadership did not predict SCQ. Supply chain quality was statistically significant in influencing both financial and non-financial business performance.

Conclusion: The transactional leadership style is an important driver of SCQ within the FMCG industry. Supply chain quality is essential in stimulating optimum business performance within the FMCG industry.

Keywords: transactional leadership; contingent reward; passive-avoidant; management by expectation; supply chain quality; financial business performance; FMCG; quantitative research.

\section{Introduction and background}

As the fast-moving consumer goods (FMCG) industry continues to grow in South Africa, so too do the problems it encounters. According to some reports (e.g. Franchise Association of South Africa 2018; Hattingh, Magnus \& Ramlakan 2016), the problems experienced by the FMCG industry are exhibited in the form of changes in patterns of trade and consumer spending behaviour, and political as well as social pressures for change, including the need to direct attention to matters regarding environmental sustainability. Several authors (Elsaid, Okasha \& Abdelghaly 2013; Loury-Okoumba \& Mafini 2018; Nze 2015) underscore that the industry is inundated by a high level of instability in demand, which leads to poor forecasting in addition to increasingly demanding consumers as well as weaknesses rooted in the interactions between firms in FMCG supply chains. For instance, consumer spending patterns in South Africa have changed significantly in the last decade since the emergence of the global economic crisis that started circa 2008 (Maynard 2016). The consumers have become more careful than before when spending and tend to consider various factors such as transportation costs, price, enhanced nutrition, package labelling and health before making a purchase (Noko 2018; Shange 2018). Moreover, as noted by Wadi and Gebhart (2017), the FMCG industry in South Africa experiences an unrelenting triad of political and financial volatility, poorly performing supply chains and complications posed by counterfeit products. These challenges present the South African FMCG industry with serious hurdles to overcome in its quest to remain relevant and successful in contributing to the socio-economic growth and development of the country.

In addition to the problems above, another dominant challenge facing the FMCG industry in South Africa is the need for suitable leadership skills. As indicated by Di Bartolo (2017), significant 
leadership gaps are evident in the FMCG industry in South Africa as the effects of the fourth industrial revolution begin to take centre stage throughout the economy. Other reports (Bruwer 2016; Supply Chain Digest 2010) indicate the presence of myopic leadership in the FMCG industry, where management is characterised by the lack of fast and effective decision-making and has an otherwise misdirected focus on operating margins and cash flows at the expense of other critical inputs such as the optimisation of human resources and supply chain management (SCM) practices. A critical and destructive result of these leadership problems in the FMCG industry is business underperformance presented through, but not limited to, declining competitiveness, low profits and an increase in unemployment within the country (Lekhanya, Olajumoke \& Nirmala 2017). Thus, to avert these consequences, business leaders are required who can understand the demands of the new digital era and offer competent, trustworthy and ethical leadership within businesses for the upliftment of the South African economy (Gordhan 2017).

\section{Aim and problem statement}

This study aimed to examine the link between transactional leadership, supply chain quality (SCQ) and business performance in the FMCG industry in the Gauteng province. As stated by Suhong et al. (2006), effective SCM has consistently become one of the most valuable tools for acquiring a competitive advantage, leading to enhanced business performance. However, supply chains are managed by people, and these include leaders and managers who have diverse orientations in their practice. Because supply chain networks are becoming more demanding, leadership within them has to become less arduous and more methodical (Cruz \& Wang 2018). Inconsistencies in leadership processes and approaches within the supply chain create complications in the execution of its supply chain responsibilities (Cruse \& Wang 2018b). One area where organisational leadership matters most is in stimulating high quality within business processes, systems and outputs (Foster 2008; Teoman \& Ulengin 2018). As mentioned by Wu, Yang and Chiang (2011), business leaders in particular have an essential role to play in ensuring an acceptable quality of their supply chains. This view inspires a continuous consideration of the relationship between leadership and SCQ.

Although there are numerous leadership styles, such as transformational, transactional, distributed, servant or other supporting leadership functions, this study places exclusive focus on the transactional leadership style. This preference is supported by Laohavichien, Fredendall and Cantrell's (2009) suggestion that among the available array of leadership styles, transactional leadership is the most appropriate and natural model of quality improvement through leadership. Also, the ultimate barometer of the effectiveness of all organisational efforts is the level of business performance (Yildiz \& Karakas 2012; Zulkiffli \& Perera 2011). Accordingly, it is important to conduct this research to gain insight into the impact of transactional leadership on SCQ and business performance in the FMCG industry.

\section{Research gaps}

There is much literature on leadership, although only a handful focuses on both leadership and SCM. An analysis of the general trends in research showed that most of the existing studies (Kuei 2001; Laohavichien et al. 2009; Tiwari \& Sharma 2017) are aligned to either the subcomponents of SCM practices or total quality management, transformational leadership and organisational performance. However, as indicated by Foster (2008), more research should be conducted in the areas of SCQ with reference to leadership and business performance and other factors such as customer-centred approaches, quality methodologies, mutually beneficial supplier relations, human resource practices and occupational safety. Within South Africa, studies that were conducted in the specific area of leadership and SCQ in the FMCG industry are uncommon. The closest evidence found is research by Rautenbach and Rothmann (2017), who included some aspects of leadership in their study of antecedents to flourishing at work in an FMCG firm. But this fact notwithstanding, that study was outside the domain of SCM. Hence, the present study contributes to the body of knowledge by being one of the first of its kind to be conducted on the linkage between transactional leadership, SCQ and business performance in the FMCG environment in South Africa.

This article is structured as follows: the next section presents a brief review of literature and the hypotheses to be tested followed by a presentation of the conceptual model. Thereafter, the research methodology is presented, succeeded by the research results and discussion. The closing sections of the article present the conclusion and managerial implications as well as the limitations and future research directions.

\section{Literature review}

The literature review briefly discusses the FMCG industry in South Africa and the research constructs such as transactional leadership, SCQ and business performance.

\section{The fast-moving consumer goods industry in South Africa}

Fast-moving consumer goods are those products that are sold quickly and at a relatively low-cost case of low marginhigh volume (Deliya 2011; Kotler \& Armstrong 2011). Examples include non-durable products that have, but are not limited to, general grocery products, soft drinks and beauty, skincare and cosmetic products (Joghee \& Pillai 2013). The opposite end of the FMCG scale consists of durable goods that are generally replaced over a longer period or never replaced, which provide usefulness over time and are not consumed in totality (Green 2016). The FMCG industry primarily concentrates on the manufacture, distribution and marketing of consumer packaged goods, and some of its principal activities include sales and marketing, financing, 
and purchasing. Fast-moving consumer goods firms are also engaged in operations, supply chain, production and general management (Economy Watch 2010).

Although the profitability of FMCG products tends to be low, with retailers finding it less profitable than the producers and suppliers, the contributions that the FMCG industry makes to the gross domestic product (GDP) are significant (Malhotra 2014). In South Africa, the FMCG industry adds about nearly R2 trillion to the GDP annually (Brand South Africa 2017). With 55.5\% (30.4 million) of South Africa's population living in poverty in 2017 and with the decline in jobs within other sectors, the FMCG industry has a critical role to play to increase its economic contribution and reduce the unemployment rate (Statistics South Africa 2017, 2018). Given these statistics, the FMCG industry has the opportunity of reducing income gaps by employing more workers, now that other competing industries such as the mining and quarrying industries are seen to be in decline and trade industries are gradually increasing (Noko 2018).

\section{Transactional leadership}

Burns (1978) and Bass (1985) developed theories of leadership in the 1970s and 1980s to explain how critical personality differences in leaders result in either transactional or transformational leadership styles. Transactional leadership occurs when leaders promote compliance by followers through both rewards and punishments (Kuhnert \& Lewis 1987). Transactional leaders are those who provide followers with something they need in exchange for something the leader expects them to achieve, based on the fulfilment of contractual commitments (Antonakis, Avolio \& Sivasubramaniam 2003; Yukl 2013). Transactional leadership is made up of four subcomponents, namely contingent reward, management by expectation (active), management by expectation (passive) and passive-avoidant (Yukl 2013), which will be briefly described below.

Contingent reward practices refer to leadership behaviours that concentrate on clarifying the role and task requirements and giving followers material or psychological rewards dependent on the fulfilment of contractual responsibilities (Camps \& Torres 2010). Management by exception (active) refers to the active observance of leaders whose objectives are to guarantee an adherence to standards (Penno 2017). In management by exception (passive), leaders only intercede after a non-conformance has transpired or after errors have already transpired (Penno 2017). Transactional passive-avoidant leadership represents the absence of a transaction of sorts concerning leadership in which the leader eludes to making decisions, resigns responsibility and does not use his or her authority (Robbins, Judge \& Sanghi 2007). It is considered active to the degree that the leader opts to avoid acting (Luthans 2005). This element is considered the most passive and ineffective form of leadership (Chaudhry \& Javed 2012).

Leadership is imperative for motivating followers and activating resources to achieve organisational objectives, including in areas that are vital for innovation, change management and business performance (Antonakis \& House 2014). According to Bass et al. (2003), transactional leadership has a positive impact on performance in that leaders explain precisely what the expectations are and then reward accomplishments that contribute to improved performance. This leads to the following hypotheses:

$\mathbf{H}_{1}$ : Contingent reward leadership has an influence on SCQ in the FMCG industry.

$\mathbf{H}_{2}$ : Management by expectation (active) leadership has an influence on SCQ in the FMCG industry.

$\mathbf{H}_{3}$ : Passive-avoidant leadership influences SCQ in the FMCG industry.

\section{Supply chain quality}

Lin, Kuei and Chai (2013) define SCQ as a coordinated approach to linking strategic leadership and operational activities of a supply chain system in an organised manner to prevent unsolicited deviations, and ensure accountability of supply chain cohorts with refined systems that build capable supply networks. Various authors (Foster 2008; Huo et al. 2019) mention that there has been an increased focus on integrating quality into the supply chain. However, although the effects of SCQ on quality-related performance have been considered in research, questions surrounding its relationship with business performance remain relatively unanswered (Fish 2011). A study by Uwamahoro (2018) found that quality-related performance varies according to the different levels of SCQ integration achieved. The same study found higher SCQ to be associated with superior service and delivery performance, resulting in a positive impact on business performance, which also allowed for greater flexibility to meet customer requirements. $\mathrm{Yu}$ and Huo (2018) further add that integrating quality management and SCM has become important in order for firms to achieve a competitive advantage and that the concept of SCQ management is becoming progressively recognised. This leads to the following hypotheses:

$\mathbf{H}_{4}$ : SCQ influences non-financial performance in the FMCG industry.

$\mathbf{H}_{5}$ : SCQ influences financial performance in the FMCG industry.

\section{Business performance}

Business performance is defined by Smith and Reece (1999) as a firm's operational capacity to meet shareholder expectations. It should be measured to assess and analyse actual performance against its set targets for both operational and strategic performance (Zulkiffli \& Perera 2011). Motives for measuring business performance include monitoring and control, facilitating the drive for improvement, fully exploiting the improvement effort to achieve alignment with organisational goals and objectives and rewarding and instilling discipline (Bititci, Carrie \& McDevitt 1997; Kellen 2003).

There are two major classifications of business performance. Kellen (2003) highlights that business performance measurement tools can either be subjective or objective. In this study, business performance is measured using 
subjective measures. Subjective measures are influenced by the observer's judgment or perceptions of how the business is performing (Aljena 2017; Mikelsone \& Liela 2016). In contrast, objective measures involve impartial measurement that is without bias or prejudice and include performance measures such as financial indices to provide actual quantifiable performance feedback (Mikelsone \& Liela 2016). Objective business performance measures include current stock price, real revenue growth, return on assets, cost of capital and working capital (Nur \& Zulkiffli 2014).

Kaplan and Norton (1992) recognised the importance of maintaining a balance between financial and non-financial measures and developed the balanced scorecard (BSC), which classifies business performance into four metrics, namely financial performance, customer satisfaction, internal business processes, and the innovation and learning perspective. Likewise, the present study uses a two-pronged classification of business performance which, thus, identifies financial and non-financial metrics and applies them as indicators (Carpi, Douglas \& Gascon 2018; Coe \& Letza 2014). This provides an avenue to measure the impact of SCQ on business performance in a balanced manner, involving both financial and non-financial indicators (Kellen 2003).

\section{Conceptual model}

In line with the above review of literature, the conceptual model presented in Figure 1 was developed.

As shown in Figure 1, the predictor variable is transactional leadership, represented by three subcomponents, namely contingent reward, management by expectation (active) and passive-avoidant. The mediating variable is SCQ that is connected to business performance, which is the outcome variable. This study included three of the four subcomponents of transactional leadership. The fourth subcomponent (management by exception - passive) was not considered in the study because its items were discarded during the data analysis since they were cross-loading with others in the factor analysis procedure (refer to Table 3 and its preceding paragraph).

\section{Research methodology}

The research methodology discusses the research design and sample, research instrument, and the collection and analysis of data.

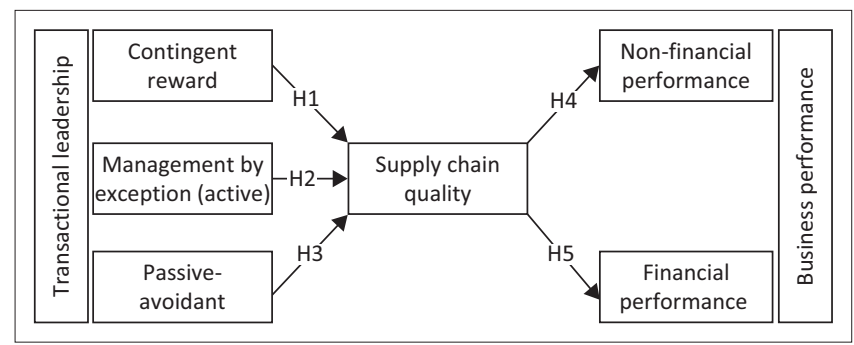

H, Hypothesis.

FIGURE 1: Conceptual model for the study.

\section{Research design and sample}

For this study, a quantitative approach was followed, in which numeric data were applied in objectively measuring the variables of interest and determining the possible relationships between them (Leedy \& Ormrod 2015). The study also used a cross-sectional survey strategy, in which data were collected from the selected respondents in a single snapshot of time (Blumberg, Cooper \& Schindler 2014).

The target population for this study consisted of managers and employees of two selected firms operating within the FMCG industry in the Gauteng province. From this population, respondents were selected using a nonprobability purposive sampling technique. Purposive sampling is the deliberate choice of a specific respondent because of the qualities she or he possesses (Battaglia 2011; Etikan, Musa \& Alkassim 2016). It was the sampling technique of choice in this study because respondents had to have some elementary knowledge of the subject under investigation, as demonstrated by their level of education, as well as sufficient knowledge of the FMCG industry which is indexed on their work experience.

A total of 150 questionnaires were distributed to managers and professional employees of the selected firms. A sum of 82 were returned, of which 73 were used in the final data analysis, which produced a response rate of $48.7 \%$. A total of nine questionnaires were discarded because they had errors. The sample size of 73 respondents was considered to be acceptable because, as recommended by Forcino et al. (2015), sample sizes for multivariate analysis in quantitative studies should have at least 50 respondents. Other authors (DeVellis 2017; De Winter, Dodou \& Wieringa 2009) suggest that the rule of thumb for factor analysis (the procedure also applied in this study) should be at least $n=50$. Thus, the sample size of $n=73$ was adequate to deliver sufficient data to minimise statistical errors, and increase validity as well as reliability and statistically significant results.

\section{Research instrument}

This study used a four-section self-administered survey questionnaire to collect data. Section A of the questionnaire provided information on the demographic profiles of the individual respondents. Section B consisted of 14 questions focusing on leadership styles as adapted from the Management Leadership Questionnaire (MLQ) (Bass \& Avolio 2000). The questions in this section were presented in five-point Likerttype scales anchored by 1 - not at all, to 5 - frequently, if not always. Section $\mathrm{C}$ sought responses on SCQ using a six-item scale adapted from previous studies by Koh et al. (2007) and Li et al. (2009). In section C, questions were presented in fivepoint Likert-type scales anchored by 1 - strongly disagree, to 5 - strongly agree. Section D sought responses to business performance and used seven questions adapted from studies by Koh et al. (2007) and Li et al. (2009). The questions in section $\mathrm{D}$ were presented in five-point Likert-type scales anchored by 
1 - much worse than industry average, to 5 - much better than the industry average. Measurement scale items are indicated in Tables 3-5.

\section{Data collection}

A survey questionnaire was distributed using a combination of the drop and collect and email methods. The targeted respondents were given 1 week in August 2017 to complete the questionnaire. A confidentiality agreement and an informed consent form accompanied each questionnaire to facilitate the data collection. All respondents in the survey completed the same questionnaire and were not given incentives for participating in the study.

\section{Data analysis}

The collected data were analysed using the Statistical Packages for the Social Sciences (SPSS version 25.0). The statistical analysis techniques used in the study included descriptive statistics, exploratory factor analysis (EFA), correlations and regression analysis. Descriptive statistics such as frequencies and percentages are used to summarise the collected data and to show the patterns in that data (Nick 2007). In this study, descriptive statistics were used to analyse the demographic profile of respondents. Exploratory factor analysis is a procedure used to determine the underlying structure of a set of variables (Norris \& Lecavalier 2009). In the present study, the EFA procedure was applied to determine the factor structure of the collected data regarding the constructs of the study, namely transformational leadership, SCQ and business performance. Correlation analysis is a statistical procedure used to test the strength and direction of linear associations between research constructs (Székely, Rizzo \& Bakirov 2007). Regression analysis is a statistical procedure for testing for causality or prediction between a set of research constructs (Freedman 2005). Both correlation and regression analyses were used to test the relationships between the constructs under consideration in the current study.

\section{Ethical considerations}

The study was conducted after an ethical clearance had been granted by the Ethics Review Committee of the School of Business Leadership Research of the University of South Africa (Reference number: 2018_SBL_MBL_161_FA).

\section{Research results}

The results section discusses the demographic profile of respondents, the application of EFA, correlations and regression analysis.

\section{Demographic profile of respondents}

The profile of the respondents is presented in Table 1.

As shown in Table 1, males constituted 60.3\% $(n=44)$ and females constituted $39.7 \%(n=29)$ of the sample. The age
TABLE 1: Demographic details of the respondents.

\begin{tabular}{|c|c|c|c|}
\hline Variable & Categories & Frequency $(n)$ & $\%$ \\
\hline \multirow[t]{2}{*}{ Gender } & Male & 44 & 60.3 \\
\hline & Female & 29 & 39.7 \\
\hline Total & & 73 & 100 \\
\hline \multirow[t]{6}{*}{ Age group } & $18-25$ years & 5 & 6.8 \\
\hline & $26-30$ years & 16 & 21.9 \\
\hline & $31-35$ years & 17 & 23.3 \\
\hline & $36-40$ years & 8 & 11.0 \\
\hline & $41-50$ years & 15 & 20.5 \\
\hline & Above 50 years & 12 & 16.4 \\
\hline Total & & 73 & 100 \\
\hline \multirow{7}{*}{$\begin{array}{l}\text { Highest } \\
\text { qualification }\end{array}$} & Matric & 16 & 21.9 \\
\hline & Diploma & 30 & 41.1 \\
\hline & Degree & 16 & 21.9 \\
\hline & Postgraduate diploma & 1 & 1.4 \\
\hline & Master's & 3 & 4.1 \\
\hline & Professional qualification & 6 & 8.2 \\
\hline & Other & 1 & 1.4 \\
\hline Total & & 73 & 100 \\
\hline \multirow{6}{*}{$\begin{array}{l}\text { Employment } \\
\text { period }\end{array}$} & Less than 2 years & 12 & 16.4 \\
\hline & Between 2 and 5 years & 23 & 31.5 \\
\hline & Between 6 and 10 years & 15 & 20.5 \\
\hline & Between 11 and 15 years & 17 & 23.3 \\
\hline & Between 16 and 20 years & 4 & 5.5 \\
\hline & More than 20 years & 2 & 2.7 \\
\hline Total & & 73 & 100 \\
\hline \multirow[t]{3}{*}{ Race } & African & 52 & 71.2 \\
\hline & Indian or Asian & 5 & 6.8 \\
\hline & White & 16 & 21.9 \\
\hline Total & & 73 & 100 \\
\hline \multirow{6}{*}{$\begin{array}{l}\text { Position in } \\
\text { organisation }\end{array}$} & Top management & 1 & 1.4 \\
\hline & Senior management & 7 & 9.6 \\
\hline & Middle management & 15 & 20.5 \\
\hline & Junior management & 23 & 31.5 \\
\hline & Semi-skilled & 26 & 35.6 \\
\hline & Unskilled & 1 & 1.4 \\
\hline Total & & 73 & 100 \\
\hline \multirow{6}{*}{$\begin{array}{l}\text { Occupational } \\
\text { area }\end{array}$} & Senior officials and managers & 9 & 12.3 \\
\hline & Professionals & 10 & 13.7 \\
\hline & Technicians and associate professionals & 12 & 16.4 \\
\hline & Clerks & 12 & 16.4 \\
\hline & Service and sales workers & 12 & 16.4 \\
\hline & Plant and machine operators and assemblers & 18 & 24.7 \\
\hline Total & & 73 & 100 \\
\hline
\end{tabular}

groups most represented in the sample were 26-30 years at $21.9 \%(n=16), 31-35$ years at $23.3 \%(n=17)$ and $41-50$ years at $20.5 \%(n=15)$. In the highest qualification category, diploma holders constituted $41 \%(n=30)$, while matriculation and degree holders made up $21.9 \%(n=16)$ apiece. In terms of the employment period, $31.5 \%(n=23)$ of the respondents had 2-5 years' work experience, followed by those with $11-15$ years at $23.3 \%(n=17)$. The race category composed of Africans with $71.2 \%(n=52)$, Indians with $6.8 \%(n=5)$ and white people with $21.9 \%(n=16)$. With reference to the positions occupied, semi-skilled respondents were the highest in terms of representation in the sample at $35.6 \%$ $(n=26)$, followed by junior management with $31.5 \%(n=23)$. Occupations represented in the sample constituted the following: senior officials and managers with $12.3 \%(n=9)$; professionals with $13.7 \%(n=10)$; technicians and associate 
professionals, clerks, and service and sales workers all with $16.4 \%(n=12)$, respectively; and plant and machine operators and assemblers followed with $24.7 \%(n=18)$.

\section{Exploratory factor analysis}

Because the measurement scales were adapted from other studies, an EFA procedure was performed to determine the factor structure of the data collected in the study. A KaiserMeye-Olkin (KMO) test of sampling adequacy and the Bartlett's test of sphericity were performed to assess whether the data captured were suitable for EFA. The results of the Bartlett's and the KMO tests are presented in Table 2.

As indicated in Table 2, the $\mathrm{KMO}$ was 0.664 for the transactional leadership scale, 0.744 for the SCQ scale and 0.804 for the business performance scale. These values were above the 0.5 minimum threshold suggested by Kaiser (1974). The Bartlett's test yielded significant chi-squares of 273.146 $(d f=120)$ for the transactional leadership scale, 222.929 $(d f=15)$ for the SCQ scale and 161.826 $(d f=21)$ for the business performance scale. These test results were all significant at the $5 \%$ level. Because the results of the Bartlett's and the KMO tests were within the recommended thresholds, it was determined that data were factorable, and hence EFA could be performed.

\section{Exploratory factor analysis for the transactional leadership scale}

The scale used to measure transactional leadership was initially composed of 14 items. The EFA was conducted in line with the procedure undertaken by Bradley (2010), in which the default method was to retain items with factor loadings greater than or equal to 0.50 and with an eigenvalue either equal to or greater than 1 . In addition, the percentage of variance explained and the screen plot criterion guided the

TABLE 2: The Kaiser-Meye-Olkin measure and the Bartlett test results.

\begin{tabular}{lcccc}
\hline Constructs & $\begin{array}{c}\text { KMO measure } \\
\text { of sampling } \\
\text { adequacy }\end{array}$ & \multicolumn{3}{c}{ Bartlett's test of sphericity } \\
\cline { 3 - 5 } & $\begin{array}{c}\text { Approximate } \\
\text { chi-square }\end{array}$ & $\begin{array}{c}\text { Degrees of } \\
\text { freedom }\end{array}$ & $\begin{array}{c}\text { Significance } \\
\text { level }\end{array}$ \\
\hline Transactional leadership & 0.664 & 273.146 & 120 & 0.000 \\
Supply chain quality & 0.744 & 222.929 & 15 & 0.000 \\
Business performance & 0.804 & 161.826 & 21 & 0.000 \\
\hline
\end{tabular}

KMO, Kaiser-Meyer-Olkin. extraction of factors. Although all factor loadings for the transactional leadership scale were greater than 0.5, five items (TL3, TL9, TL10, TL15 and TL16) were dropped during the factor analysis because of cross-loadings. The factor extraction procedure produced a three-factor structure. Table 3 presents the rotated factor solution for the transactional leadership scale.

As shown in Table 3, three transactional leadership factors with eigenvalues greater than 1 were extracted in the EFA. Factor 1 consisted of three items, was labelled as contingent reward, had an eigenvalue of 2.491 and contributed to $22.64 \%$ of the variance in transactional leadership. Factor 2 consisted of three items, was labelled as passive-avoidant, had an eigenvalue of 1.808 and contributed to $16.4 \%$ of the variance in transactional leadership. Factor 3 also consisted of three items, was labelled as management by expectation (active), had an eigenvalue of 1.6 and contributed to $14.46 \%$ of the variance in transactional leadership. Therefore, overall, these three factors explained $53.63 \%$ of the variance in transactional leadership.

Concerning their reliabilities, as measured using the Cronbach's alpha coefficient, the three factors had reliabilities ranging from 0.604 to 0.707 . These values were in line with the recommendation by Hair et al. (2014), that Cronbach's alpha values above 0.6 are acceptable for measuring reliability. Item TL1 was dropped during scale purification because it had an item-total correlation which was less than the recommended minimum of 0.3 (Field 2005) and was therefore classified as a 'garbage' item that was not correlating well with the scale.

\section{Exploratory factor analysis for the supply chain quality scale}

The EFA procedure was also conducted for the SCQ scale. Initially, the scale was composed of six items, and two of them (SCQ4 and SCQ5) were discarded because of cross-loadings. The rotated factor solution for the SCQ scale is presented in Table 4.

The EFA process reveals that only one factor captured all the subcomponents of SCQ. With an eigenvalue of 3.376 , the total variance explained for the SCQ factor was

TABLE 3: Three-factor rotated structure for the transactional leadership scale.

\begin{tabular}{|c|c|c|c|c|}
\hline \multirow[t]{2}{*}{ Item code } & \multirow[t]{2}{*}{ Item description } & \multicolumn{3}{|c|}{ Factor } \\
\hline & & $\begin{array}{c}1 \\
\text { Contingent reward }\end{array}$ & $\begin{array}{c}2 \\
\text { Management by } \\
\text { expectation (active) }\end{array}$ & $\begin{array}{c}3 \\
\text { Passive-avoidant }\end{array}$ \\
\hline TL2 & Re-examine critical assumptions to question whether they are appropriate & 0.817 & -0.079 & 0.127 \\
\hline TL8 & Make clear what one can expect to receive when performance goals are achieved & 0.808 & -0.120 & -0.110 \\
\hline TL6 & Discuss in specific terms who is responsible for achieving performance targets & 0.597 & -0.142 & 0.234 \\
\hline TL14 & Avoid making decisions & -0.070 & 0.815 & 0.042 \\
\hline TL4 & Avoid getting involved when important issues arise & -0.251 & 0.643 & -0.119 \\
\hline TL13 & Direct my attention towards failures to meet standards & 0.034 & -0.022 & 0.792 \\
\hline TL12 & Keep track of all mistakes & 0.082 & 0.097 & 0.768 \\
\hline TL11 & Concentrate my full attention on dealing with mistakes, complaints and failures & 0.022 & -0.031 & 0.640 \\
\hline
\end{tabular}

Note: Bold values indicate items that loaded under the factor. 
TABLE 4: Unidimensional factor structure for the supply chain quality scale.

\begin{tabular}{llc}
\hline Item code & Description & $\begin{array}{c}\text { Factor } 1 \\
\text { Supply chain quality }\end{array}$ \\
\hline SCQ1 & $\begin{array}{l}\text { Our company implements frequent quality } \\
\text { improvements }\end{array}$ & 0.934 \\
SCQ2 & $\begin{array}{l}\text { The product has higher technical durability } \\
\text { than competitors }\end{array}$ & 0.794 \\
SCQ3 & $\begin{array}{l}\text { The product provided conforms to } \\
\text { prearranged specifications }\end{array}$ & 0.816 \\
SCQ6 & $\begin{array}{l}\text { Our company implements frequent cost- } \\
\text { reduction measures }\end{array}$ & 0.720 \\
\hline
\end{tabular}

Note: Eigenvalue is 3.376 for supply chain quality. Reliability (Cronbach's alpha) is 0.895 for supply chain quality. Total variance explained is 56.267 for supply chain quality.

SCQ, supply chain quality.

$56.27 \%$. The reliability of the factor as measured by the Cronbach's alpha was 0.895, which is regarded as acceptable by Nunnally (1978).

\section{Exploratory factor analysis for the business performance scale}

The business performance scale was initially composed of seven items. In applying the EFA procedure to determine the factor structure of this scale, two factors were extracted, and none of the seven items were dropped from the scale. The resulting factor structure is presented in Table 5.

The eigenvalue is 3.378 for non-financial performance and 1.134 for financial performance. Reliability (Cronbach's alpha) is 0.750 for non-financial performance and 0.785 for financial performance. Total variance explained is 48.257 for non-financial performance and 16.203 for financial performance.

As shown in Table 5, two business performance factors with eigenvalues greater than 1 were extracted in the EFA. Factor 1 consisted of four items, was labelled as non-financial performance, had an eigenvalue of 3.3378 and contributed to $48.257 \%$ of the variance in business performance. Factor 2 consisted of three items, was labelled as financial performance, had an eigenvalue of 1.134 and contributed to $16.2 \%$ of the variance in business performance. Overall, these two factors explained $64 \%$ of the variance in business performance. The Cronbach's alpha values for the two factors were both above the recommended minimum cut-off value of 0.7 , which implies that the two scales were internally consistent or reliable.

\section{Correlation analysis}

Correlation analysis was applied to measure the linear associations between transactional leadership subcomponents, SCQ and business performance. Pearson correlation analysis, which assesses the degree that quantitative variables are linearly related in a sample (Maxwell \& Moores 2007), was used. The results of this analysis are presented in Table 6 .

As shown in Table 6, positive inter-factor correlations ranging from $r=0.141$ to $r=0.521$ were observed between contingent reward, management by exception, SCQ and the two subcomponents of business performance. This result depicts that an increase in one factor would attract
TABLE 5: Two-factor rotated structure for the business performance scale.

\begin{tabular}{llcc}
\hline Item code & Description & \multicolumn{2}{c}{ Factor } \\
\cline { 3 - 4 } & Customer satisfaction & $\begin{array}{c}\mathbf{1} \\
\text { Non-financial } \\
\text { performance }\end{array}$ & $\begin{array}{c}\mathbf{2} \\
\text { Financial } \\
\text { performance }\end{array}$ \\
\hline BP6 & $\mathbf{0 . 8 0 6}$ & 0.068 \\
BP2 & Productivity & $\mathbf{0 . 7 5 2}$ & 0.219 \\
BP7 & Supplier performance & $\mathbf{0 . 7 1 7}$ & 0.204 \\
BP1 & Employee satisfaction & $\mathbf{0 . 6 4 5}$ & 0.382 \\
BP5 & Cost savings & 0.142 & $\mathbf{0 . 8 6 7}$ \\
BP3 & Sales or revenue growth & 0.167 & $\mathbf{0 . 8 4 8}$ \\
BP4 & Profitability & 0.348 & $\mathbf{0 . 6 9 7}$ \\
\hline
\end{tabular}

Note: Bold values indicate items that loaded under the factor.

TABLE 6: Correlations: Transformational leadership, supply chain quality and business performance.

\begin{tabular}{lcccccc}
\hline Constructs & CR & PA & MBE (A) & SCQ & NFBP & FBP \\
\hline CR & 1 & - & - & - & - & - \\
PA & -0.165 & 1 & - & - & - & - \\
MBE (A) & 0.141 & 0.011 & 1 & - & - & - \\
SCQ & $0.496 * *$ & -0.139 & $0.117^{*}$ & 1 & - & - \\
NFBP & $0.219 *$ & -0.082 & $0.195^{*}$ & $0.424 * *$ & 1 & - \\
FBP & $0.389 * *$ & -0.117 & $0.218^{*}$ & $0.470 * *$ & $0.521 * *$ & 1 \\
\hline
\end{tabular}

$\mathrm{CR}$, continent reward; $\mathrm{PA}$, passive-avoidant; $\mathrm{MBE}(\mathrm{A})$, management by expectation (active); SCQ, supply chain quality; NFBP, non-financial business performance; FBP, financial business performance.

*, Correlation is significant at the 0.05 level (two-tailed).

**, Correlation is significant at the 0.01 level (two-tailed)

an increase in the other factors as well and vice versa. However, correlations between passive-avoidant and other constructs were either almost non-existent (e.g. with management by exception) or negative (e.g. with the rest of the constructs). These negative correlations depict an inverse association in which an increase in the passive-avoidant leadership would result in decreases in SCQ and both financial and non-financial performance.

\section{Regression analysis}

To determine whether there were predictive relationships between the different variables, regression analysis was used. Regression analysis is a statistical technique that facilitates the summarising of the relationship between a variable of interest and one or more variables foreseen to influence that variable (Schroeder, Sjoquist \& Stephan 2017). In this study, regression analysis was applied using the enter method, in which all variables are entered in a single step. Because there were three sets of relationships, three regression equations and models were computed. In the first regression model, contingent reward, passive-avoidant and management by expectation (active) were entered as the independent variables, while SCQ was entered as the dependent variable. The linear regression equation for model 1 was formulated as follows:

$\mathrm{SCQ}=\beta_{0}+\beta_{1}$ (contingent reward $)+\beta_{2}$ (passive-avoidant $)$ $+\beta_{3}$ (management by expectation; active) [Eqn 1]

where SCQ is supply chain quality, $\beta_{0}$ is the constant or intercept and $\beta_{1-3}$ are the coefficients of the independent variables. 
The results of the first regression analysis are presented in Table 7.

As shown in Table 7, the regression analysis in model 1 revealed that the three transactional leadership predictors (adjusted $R^{2}=0.252$ ) explained approximately $25 \%$ of the variance in SCQ. This further denotes that the remaining 75\% of the variance in SCQ is explained by other factors that were not considered in this study. The study considered the effect of multicollinearity, which suggests that several of the independent variables are closely linked in some way, which causes unusual results when attempting to study how well individual independent variables contribute to an understanding of the dependent variable (O'Brien 2007). Murray et al. (2012) suggest that the variance inflation factor (VIF) value should preferably be below 10. Concerning tolerance, larger tolerance values of more than 0.5 are more desirable as they are more indicative of lesser problems with multicollinearity (Denis 2011). Table 7 further shows that VIF values were lower than the recommended maximum of 10 and their tolerance values were higher than 0.5 minimum cut-off value. Thus, multicollinearity problems were almost negligible in the model.

In the second regression model, SCQ was entered as the independent variable, while non-financial business performance was entered as the dependent variable. The linear regression equation for model 2 was formulated as follows:

$\mathrm{NFBP}=\beta_{0}+\beta_{4}(\mathrm{SCQ})$

where NFBP is non-financial business performance, $\beta_{0}$ is the constant or intercept and $\beta_{4}$ is the coefficient for SCQ.
The results of this regression analysis are presented in Table 8 .

Table 8 reveals that in the regression analysis in model 2 , the single predictor variable (SCQ: adjusted $R^{2}=0.180$ ) explained approximately $18 \%$ of the variance in non-financial business performance in this study. Concerning evaluating the assumptions of multicollinearity, the VIF for the predictor (1.000) was acceptable because it was less than 10 and the tolerance value (1.000) was higher than 0.5. Hence, multicollinearity problems were minimum in this regression model.

In the third regression model, SCQ was entered as the independent variable and financial business performance as the dependent variable. The linear regression equation for this model was formulated as follows:

$\mathrm{FBP}=\beta_{0}+\beta_{4}(\mathrm{SCQ})$

[Eqn 3]

where FBP is financial business performance, $\beta_{0}$ is the constant or intercept and $\beta_{4}$ is the coefficient for SCQ.

The results of this regression analysis are presented in Table 9.

Table 9 shows that in the regression analysis in model 3, the single predictor (SCQ: adjusted $R^{2}=0.210$ ) explained approximately $21 \%$ of the variance in financial business performance. In further assessing the assumptions of multicollinearity, the VIF for the predictor (1.000) was acceptable because it was less than 10, while the tolerance

TABLE 7: Regression model 1: Transactional leadership and supply chain quality.

\begin{tabular}{|c|c|c|c|c|c|c|c|}
\hline \multirow{3}{*}{$\begin{array}{l}\text { Independent variables: } \\
\text { transactional leadership }\end{array}$} & \multicolumn{2}{|c|}{ Unstandardised coefficients } & \multicolumn{5}{|c|}{ Dependent variable: supply chain quality } \\
\hline & \multirow[t]{2}{*}{$\beta$} & \multirow[t]{2}{*}{ Standard error } & \multirow{2}{*}{$\begin{array}{c}\text { Beta } \\
(\beta)\end{array}$} & \multirow[t]{2}{*}{$t$} & \multirow{2}{*}{ Sig. } & \multicolumn{2}{|c|}{ Collinearity statistics } \\
\hline & & & & & & Tolerance & VIF \\
\hline Constant & 3.053 & 0.766 & & 3.983 & 0.000 & - & - \\
\hline $\mathrm{CR}$ & 0.705 & 0.157 & 0.479 & 4.487 & 0.000 & 0.952 & 1.050 \\
\hline $\operatorname{MBE}(A)$ & 0.600 & 0.130 & 0.500 & 0.479 & 0.000 & 0.979 & 1.021 \\
\hline PA & -0.081 & 0.142 & -0.060 & -0.569 & 0.571 & 0.972 & 1.029 \\
\hline
\end{tabular}

$R, 0.502$; adjusted $R^{2}, 0.252 ; F, 7.735$.

$\mathrm{CR}$, continent reward; PA, passive-avoidant; MBE (A), management by expectation (active); Sig., significance; $p$, $p$-value; $\beta$, beta; VIF, variance inflation factor.

TABLE 8: Regression model 2: Supply chain quality and non-financial business performance.

\begin{tabular}{|c|c|c|c|c|c|c|c|}
\hline \multirow{3}{*}{$\begin{array}{l}\text { Independent variable: } \\
\text { supply chain quality }\end{array}$} & \multicolumn{2}{|c|}{ Unstandardised coefficients } & \multicolumn{5}{|c|}{ Dependent variable: non-financial business performance } \\
\hline & \multirow[t]{2}{*}{$\beta$} & \multirow[t]{2}{*}{ Standard error } & \multirow{2}{*}{$\begin{array}{c}\text { Beta } \\
(\boldsymbol{\beta})\end{array}$} & \multirow[t]{2}{*}{$t$} & \multirow{2}{*}{$\begin{array}{c}\text { Sig. } \\
(p)\end{array}$} & \multicolumn{2}{|c|}{ Collinearity statistics } \\
\hline & & & & & & Tolerance & VIF \\
\hline Constant & 2.368 & 0.378 & - & 6.265 & 0.000 & - & - \\
\hline Supply chain quality & 0.255 & 0.065 & 0.424 & 3.947 & 0.000 & 1.000 & 1.000 \\
\hline
\end{tabular}

$R, 0.424$; adjusted $R^{2}, 0.180 ; F, 15.57$.

Sig., significance; VIF, variance inflation factor; $\beta$, beta; $p$, $p$-value.

TABLE 9: Regression model 3: Supply chain quality and financial business performance.

\begin{tabular}{|c|c|c|c|c|c|c|c|}
\hline \multirow{3}{*}{$\begin{array}{l}\text { Independent variable: } \\
\text { supply chain quality }\end{array}$} & \multicolumn{2}{|c|}{ Unstandardised coefficients } & \multicolumn{5}{|c|}{ Dependent variable: financial business performance } \\
\hline & \multirow[t]{2}{*}{$\beta$} & \multirow[t]{2}{*}{ Standard error } & \multirow{2}{*}{$\begin{array}{c}\text { Beta } \\
(\boldsymbol{\beta})\end{array}$} & \multirow[t]{2}{*}{$t$} & \multirow{2}{*}{ Sig. } & \multicolumn{2}{|c|}{ Collinearity statistics } \\
\hline & & & & & & Tolerance & VIF \\
\hline Constant & 1.535 & 0.455 & & 3.372 & 0.001 & - & - \\
\hline Supply chain quality & 0.349 & 0.078 & 0.470 & 4.486 & 0.000 & 1.000 & 1.000 \\
\hline
\end{tabular}

$R, 0.470$; adjusted $R^{2}, 0.210 ; F, 20.122$.

Sig., significance; VIF, variance inflation factor; $\beta$, beta; $p$, $p$-value. 
value (1.000) was also higher than 0.5 . This also signals that multicollinearity problems were minimum in this model.

\section{Outcomes of hypotheses tests}

The five relationships that were hypothesised in the conceptual framework (Figure 1) of this study were tested using both correlation and regression analyses. The outcomes of the hypotheses tests that show the correlation coefficients, beta coefficients, the corresponding $t$ and $p$-values and the outcome of each relationship are provided in Table 10

The results of the hypotheses tests show that except for $\mathrm{H}_{2^{\prime}}$ which initially suggested a positive relationship between passive-avoidant and SCQ, the other four hypotheses $\left(\mathrm{H}_{1^{\prime}} \mathrm{H}_{3^{\prime}}\right.$ $\mathrm{H}_{4}$ and $\mathrm{H}_{5}$ ) were supported. Further discussions on each hypothesised relationship are provided in the next section.

\section{Contingent reward leadership and supply chain quality}

The first hypothesised relationship $\left(\mathrm{H}_{1}\right)$, which suggested that contingent reward has an influence on SCQ, was supported. Correlation analyses indicated a moderate positive association between contingent reward and SCQ $(r=0.496$; $p<0.01)$. This result illustrates that when contingent reward increases, SCQ will also increase. Regression analysis indicates that contingent reward was statistically significant in predicting SCQ $(\beta=0.479 ; t=4.487 ; p=0.000)$, which demonstrates that the practice of contingent reward leads to SCQ. As such, there is a high likelihood of greater SCQ in FMCG environments where contingent reward is practised by leaders and managers. These results are parallel to those found in a study by Laohavichien et al. (2009), where the quality of the supply chain was higher in organisations where contingent reward was practised. Consistently, Fröber and Dreisbach (2014) found that having a strong contingent reward system in place can strengthen the competitive advantage through SCQ. A contingent reward system that is motivationally based is used to reward the achievement of goals and provides for positive reinforcement in meeting the set objectives. For instance, employees that meet their predetermined goals can be awarded some performance-based bonuses. In turn, such employees become motivated to exert additional effort in various areas of their work, leading to the improved quality of the supply chain. Thus, the awards encourage optimal performance in various areas of the organisation (Walumbwa, Wu \& Orwa 2008), which explains the positive influence on SCQ in the FMCG industry as observed in this study.

\section{Management by expectation leadership and supply chain quality}

The second hypothesised relationship $\left(\mathrm{H}_{2}\right)$, which suggested that management by expectation (active) has an influence on SCQ, was supported. There was a moderate positive association between management by expectation (active) and SCQ $(r=0.117 ; p<0.01)$ in the correlation analysis. This result presents the picture that when management by expectation (active) increases, SCQ will also increase. The regression analysis indicates that management by expectation (active) was statistically significant in predicting SCQ $(\beta=0.500 ; t=0.479 ; p=0.000)$. This result implies that the practice of management by expectation (active) leads to SCQ. For instance, when managers are attentive in monitoring the activities of their subordinates, they may easily identify areas where standards are being compromised. Such managers may then immediately apply some remedial action to address any adverse situation, which catapults both organisational inputs and outputs back to the expected standards. In this manner, there is a high likelihood of greater SCQ in FMCG environments where managers and leaders practise management by expectation (active). Willis, Clark and O'Connor (2017) found similar results which showed that a positive relationship exists between management by expectation and contextual performance. In the setting of this study, this contextual performance is represented by SCQ.

\section{Passive-avoidant leadership and supply chain quality}

The third hypothesised relationship $\left(\mathrm{H}_{3}\right)$, which suggested that passive-avoidant leadership has an influence on SCQ, was not supported. There was a weak negative association between the passive-avoidant and SCQ $(r=-0.139 ; p<0.01)$ in the correlation analysis, which implies that SCQ will decrease whenever the prevalence of passive-avoidant leadership increases. The regression analysis indicates that passive-avoidant leadership was statistically insignificant in predicting SCQ $(\beta=-0.060 ; t=-0.569 ; p=0.571)$. This result demonstrates that passive-avoidant leadership practices do not promote SCQ. Put in other words, there is a high likelihood of inadequate SCQ in FMCG environments where passive-avoidant leadership practices are common. Consistent with these results, Skogstad et al. (2014) found that passive-avoidant leadership practices may have negative consequences in critical situations where strong leadership is critical but is absent. This applies to scenarios

TABLE 10: Outcomes of hypotheses tests.

\begin{tabular}{|c|c|c|c|c|c|c|}
\hline Proposed relationship & Hypothesis & $\begin{array}{l}\text { Correlation } \\
\text { coefficient }(r)\end{array}$ & $\begin{array}{c}\text { Beta } \\
\text { coefficient }(\beta)\end{array}$ & $t$ & $p$ & Outcome \\
\hline Contingent reward $\rightarrow$ Supply chain quality & $\mathrm{H}_{1}$ & $0.496 * *$ & 0.479 & 4.487 & 0.000 & Significant and supported \\
\hline Management by expectation (active) $\rightarrow$ Supply chain quality & $\mathrm{H}_{3}$ & 0.117 & 0.500 & 0.479 & 0.000 & Significant and supported \\
\hline Supply chain quality $\rightarrow$ Non-financial business performance & $\mathrm{H}_{4}$ & $0.424 * *$ & 0.424 & 3.947 & 0.000 & Significant and supported \\
\hline Supply chain quality $\rightarrow$ Financial business performance & $\mathrm{H}_{5}$ & $0.470 * *$ & 0.470 & 4.486 & 0.000 & Significant and supported \\
\hline
\end{tabular}

*, Correlation is significant at the 0.05 level ( $p$-value, significance at the 0.05 level).

**, Correlation is significant at the 0.01 level (two-tailed). 
where superior SCQ is a requirement for the overall performance of the supply chain. For instance, when supervision is lacking, which is what happens during passive-avoidant leadership, some employees generally tend to lower the expected standards of performance and apply minimum efforts in their work (Kabede \& Demeke 2017). As a result, organisational systems and procedures suffer, leading to a decrease in quality standards. This perhaps explains why no significant relationship was found between passive-avoidant and SCQ in the present study.

\section{Supply chain quality and non-financial performance}

The fourth hypothesised relationship $\left(\mathrm{H}_{4}\right)$, which suggested that SCQ has an influence on non-financial performance, was supported. In the correlation analysis, there was a moderate positive association between SCQ and non-financial business performance $(r=0.424 ; p<0.01)$. This result shows that when there is an improvement in SCQ, non-financial business performance will likewise increase. The regression analysis indicates that SCQ was statistically significant in predicting non-financial business performance $(\beta=0.424 ; t=3.947$; $p=0.000$ ). This result suggests that there is a high prospect of significant non-financial business performance in FMCG environments where there is greater SCQ. Consistent with this result, Zizlavsky (2014) suggests that there is a positive relationship between aspects of SCQ and non-financial business performance, which is indicated in areas such as customer and employee satisfaction, innovation, systems and procedures, and social and environmental performance. Accordingly, it is important to ensure that aspects of nonfinancial business form part of supply chain performance measurement tools in the FMCG industry.

\section{Supply chain quality and financial business performance}

The fifth hypothesised relationship $\left(\mathrm{H}_{5}\right)$, which suggested that SCQ has a positive influence on financial business performance, was supported. In the correlation analysis, there was a moderate positive association between SCQ and financial business performance $(r=0.470 ; p<0.01)$. This result demonstrates that when there is an increase in SCQ, financial business performance will, in the same way, increase. The regression analysis indicates that SCQ was statistically significant in predicting financial business performance $(\beta=0.424 ; t=3.947 ; p=0.000)$. This result exhibits the finding that there is a high probability of higher financial business performance in FMCG environments where there is greater SCQ. In sync with this result, Lin et al. (2005) found a causal link between quality management practices that incorporate SCQ subcomponents and economic performance. Hence, the ability of a business in the FMCG industry to achieve better financial results is also linked to the quality of the supply chain in which the business operates.

\section{Conceptual model with final results}

The conceptual model showing the final results is presented in Figure 2.

The final model reveals the finding that contingent reward leadership exerted the highest influence on SCQ. In turn, SCQ had an almost similar positive influence on both financial and non-financial performance.

\section{Conclusions, theoretical and managerial implications}

This study aimed to investigate the link between transactional leadership, SCQ and business performance in the FMCG industry in South Africa. The study reveals that there is a positive relationship between SCQ and two transactional leadership styles, namely contingent reward and management by expectation (active). The third dimension of transactional leadership (passive-avoidant) neither correlates with nor predicts SCQ. The study further shows that SCQ is positively related to both financial and non-financial business performance. Thus, the study concludes that the right mix of transactional leadership styles positively contributes to SCQ in the FMCG industry. The study further concludes that SCQ contributes to both financial and non-financial business performance in the FMCG industry. The overall conclusion is that leadership practices are of material value in determining the quality of the supply chain and the performance of the FMCG industry.

This study provides both academic and practical implications. From an academic standpoint, the study provides information on how leadership practices - in this case, transactional leadership - can shape SCM outcomes such as SCQ and business performance in the FMCG industry. This information may be used for the benefit of individuals as well as scholars interested in the fields of both leadership and SCM.

From a management position, the insights generated in this study provide managers and practitioners with the essential understanding of leadership factors that can impact SCQ and business performance. The study suggests that to improve SCQ, efforts should also be extended to leadership practices in place in the business organisation. To improve SCQ within the FMCG industry, managers should adapt their leadership traits to those practices that have a positive influence on SCQ and practice less of the traits that have a negative impact on SCQ. In this case, this denotes that to improve SCQ, managers

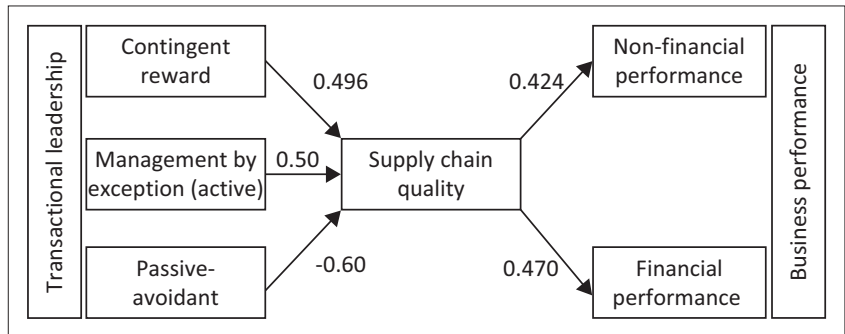

FIGURE 2: Conceptual model with final results. 
in the FMCG industry should place more emphasis on both contingent reward and management by expectation (active) while avoiding the passive-avoidant style of leadership. Managers in that industry should be more pragmatic in their approach to leadership to ensure that they create a superior SCQ for their firms. To achieve this status, it is important to ensure that employees participate in decision-making and that transparency is built through the sharing of information. There should be a drive for the recruitment of people who have a positive mindset, and this should be supported by a structured reward and recognition system. It is further essential to build trust within teams and to make an appeal to the values of employees, which should be aligned with the firm's values. These actions will, to a large extent, boost the levels of motivation among employees, thereby enabling them to direct their efforts towards the achievement of the SCQ performance of the firm.

In the same way, in the diagnoses of problems related to business performance, emphasis should be placed on understanding the contribution of SCQ. It is crucial for managers to adopt and implement SCQ practices that add value and deliver an increase in their firm's financial and non-financial performance. To start with, an SCQ management system should be developed and implemented to manage the quality of the supply chain. It is important to track poor supplier quality and customer complaints, and understand the cost of poor quality. On the employee side, employee skills should be introduced through continuous learning and development. Furthermore, best practices should be shared internally and externally, and firms can invest in and adopt lean supply chain technologies. These initiatives are likely to improve SCQ, leading to enhanced business performance.

\section{Limitations and future research directions}

This study was restricted to FMCG firms in the Gauteng province, South Africa, and its sample size was limited to 73 respondents. This limits the extent to which the results can be generalised to FMCG industries in other provinces of South Africa and elsewhere. The study was also limited in its use of the non-probability purposive sampling technique, which is subject to sampling bias (Mercer et al. 2017).

The scope of the study can be expanded by the use of samples drawn from several South African provinces to ensure that the results are more representative of the FMCG industry in the country. Because the study was restricted to transactional leadership practices, other leadership styles such as transformational, distributed and servant-leadership, among others, should be considered in future research. Future studies could also examine the relationship between such leadership styles and other aspects of SCM apart from SCQ, as well as other business performance dimensions that were not considered in this study. Similar studies can be undertaken in other sectors of the economy, which provides a basis for comparison with the FMCG industry.

\section{Acknowledgements Competing interests}

The authors declare that they have no financial or personal relationships that may have inappropriately influenced them in writing this article.

\section{Authors' contributions}

E.J. conducted the literature review and research methodology section. C.M. performed the data analysis and wrote the results section of the article.

\section{Disclaimer}

The views and opinions expressed in this article are those of the authors and do not necessarily reflect the official policy or position of any affiliated agency of the authors.

\section{References}

Aljena, A., 2017, 'Value proposition management in the contemporary fine art: Case studies of six Latvian artists', Journal of Business Management 17(12), 46-61.

Antonakis, J., Avolio, B.J. \& Sivasubramaniam, N., 2003, 'Context and leadership: An examination of the nine-factor full-range leadership theory using the Multifactor Leadership Questionnaire', The Leadership Quarterly 14, 261-295. https://doi. org/10.1016/S1048-9843(03)00030-4

Antonakis, J. \& House, R.J., 2014, 'Instrumental leadership: Measurement and extension of transformational-transactional leadership theory', The Leadership Quarterly 25(4), 746-771. https://doi.org/10.1016/j.leaqua.2014.04.005

Bass, B.M., 1985, Leadership and performance beyond expectations, Free Press, New York.

Bass, B.M. \& Avolio, B.J., 2000, 'MLQ, Multifactor Leadership Questionnaire sampler set: Technical report, leader form, rater form and scoring key for MLQ Form $5 x$-short, Mind Garden, Redwood City, CA.

Bass, B.M., Avolio, B.J., Jung, D.I. \& Berson, Y., 2003, 'Predicting unit performance by assessing transformational and transactional leadership', Journal of Applied Psychology 88(2), 207-218. https://doi.org/10.1037/0021-9010.88.2.207

Battaglia, M.P., 2011, 'Non-probability sampling', in P.J. Lavrakas, (ed.), Encyclopedia of survey research methods, pp. 523-526, SAGE Publications, Thousand Oaks, CA.

Bititci, U., Carrie, A. \& McDevitt, L., 1997, 'Integrated performance measurement systems: A development guide', International Journal of Operations and Production Management 17(5-6), 522-534. https://doi.org/10.1108/01443579710167230

Blumberg, B., Cooper, D.R. \& Schindler, P.S., 2014, Business research methods, 4th edn., McGraw-Hill Education, Berkshire.

Bradley, R., 2010, 'Proposition-valued random variables as information', Synthese 175(1), 17-38. https://doi.org/10.1007/s11229-010-9741-3

Brand South Africa, 2017, SA's key economic sectors, viewed 27 January 2019, from https://www.brandsouthafrica.com/investments-immigration/business/investing/ economic-sectors-agricultural

Bruwer, J.P., 2016, 'The relationship(s) between the managerial conduct and the internal control activities of South African fast-moving consumer goods SMMEs', Doctoral thesis, Faculty of Business and Management Sciences, Cape Peninsula University of Technology, Cape Town, South Africa.

Burns, J.M., 1978, Leadership, Harper \& Row, New York.

Camps, J. \& Torres, F., 2010, 'Contingent reward leader behaviour: Where does it come from?' Systems Research and Behavioral Science 28(3), 212-230. https:// doi.org/10.1002/sres.1067

Carpi, R., Douglas, J. \& Gascon, F., 2018, Performance management: Why keeping score is so important, and so hard, viewed 01 June 2018, from https://www.mckinsey. com/business-functions/operations/our-insights/performance-management-whykeeping-score-is-so-important-and-so-hard

Chaudhry, A.Q. \& Javed, H., 2007, 'Impact of transactional and laissez-faire leadership style on motivation', International Journal of Business and Social Science 3(7), 258-264.

Coe, N. \& Letza, S., 2014, 'Two decades of balanced scorecard: A review of developments', Poznan University of Economics Review 14(1), 63-75.

Cruz, J. \& Wang, H., 2018, Transformational leadership in supply chain management, viewed 28 April 2018, from https://www.emporia.edu/ hwang4/documents/ TransformationalLeadershipInSupplyChainManagement.pdf

Deliya, M., 2011, 'Consumer behaviour towards the new packaging of FMCG products', Abhinav-National Monthly Refereed Journal of Research in Commerce \& Management 1(11), 199-211.

Denis, D., 2011, Multiple linear regression using SPSS, viewed 09 November 2018 from http://psychweb.psy.umt.edu//denis/datadecision/front/stat_II2011/psyx 521_multiple_regression_part_II.pdf

DeVellis, R.F., 2017, Scale development: Theory and applications, 4th edn., SAGE Publications, Thousand Oaks, CA 
De Winter, J.C.F., Dodou, D. \& Wieringa, P.A., 2009, 'Exploratory factor analysis with small sample sizes', Multivariate Behavioral Research 44(2), 147-181. https://doi. org/10.1080/00273170902794206

Di Bartolo, N., 2017, 'The leadership skills required in FMCG in 2017', Brand Activity Newsletter, 29 August, viewed 27 January 2019, from http://www.fastmoving. co.za/activities/the-leadership-skills-required-in-fmcg-in-2017-8150

Economy Watch, 2010, FMCG economy, viewed 21 April 2018, from http://www. economywatch.com/world-industries/fmcg.html

Elsaid, N.M., Okasha, A.E. \& Abdelghaly, A.A., 2013, 'Defining and solving the organizational structure problems to improve the performance of Ministry of State for Environmental Affairs: Egypt', International Journal of Scientific and Research Publications 3(10), 1-10.

Etikan, I., Musa, S.A. \& Alkassim, R.S., 2016, 'Comparison of convenience sampling and purposive sampling', American Journal of Theoretical and Applied Statistics 5(1), 1-4. https://doi.org/10.11648/j.ajtas.20160501.11

Field, A., 2005, Discovering statistics using SPSS, 2nd edn., SAGE Publications, London.

Fish, L.A., 2011, 'Supply chain quality management', in D. Onkal (ed.), Supply chain quality management, supply chain management - Pathways for research, p. 26, InTechOpen, London.

Forcino, F., Leighton, L.R., Twerdy, P. \& Cahill, J.F., 2015, 'Reexamining sample size requirements for multivariate, abundance-based community research: When resources are limited, the research does not have to be', PLoS One 10(6), 1-18. https://doi.org/10.1371/journal.pone.0128379

Foster, Jr. S.T., 2008, 'Towards an understanding of supply chain quality management', Journal of Operations Management 26(4), 461-467. https://doi.org/10.1016/j. jom.2007.06.003

Franchise Association of South Africa., 2018, 'Retailers react to consumer shift in spending', viewed 2 April 2019, from http://fasa.co.za/fasablog/retailers-reactconsumers-shift-spending/.

Freedman, D.A., 2005, Statistical models: Theory and practice, Cambridge University Press, Cambridge.

Fröber, K. \& Dreisbach, G., 2014, 'The differential influences of positive affect, random reward, and performance-contingent reward on cognitive control', Cognitive, Affective, \& Behavioral Neuroscience 14(2), 530-547. https://doi.org/10.3758/ s13415-014-0259-x

Gordhan, P., 2017; Budget speech 2017, viewed 27 April 2017, from http://www. treasury.gov.za/documents/national\%20budget/2017/speech/speech.pdf

Green, S., 2016, Durable vs non-durable goods: What's the difference?, viewed 31 May 2018, from https://rjofutures.rjobrien.com/market-news/2016/05/05/ durable-vs-non-durable-goods-whats-the-difference/

Hair, J., Black, W.C., Babin, B.J. \& Anderson, R.E., 2014, Multivariate data analysis, Pearson New International edn., Pearson Education, Harlow, Essex.

Hattingh, D., Magnus, K. \& Ramlakan, S. 2016, 'South Africa's cautious consumer: In light of the country's challenging economic environment, how can consumergoods companies and retailers succeed in South Africa?' McKinsey \& Company Report, viewed 2 April 2019 from https://www.mckinsey.com/industries/ consumer-packaged-goods/our-insights/south-africas-cautious-consumer.

Huo, B., Ye, Y., Zhao, X. \& Zhu, K., 2019, 'Supply chain quality integration: A taxonomy perspective', International Journal of Production Economics 207(1), 236-246. https://doi.org/10.1016/j.ijpe.2016.05.004

Joghee, S. \& Pillai, P., 2013, 'Brand influence on buying FMCG products in UAE: An empirical study', European Journal of Business and Management 5(25), 9-16.

Kabede, A.M. \& Demeke, G.W., 2017, 'The influence of leadership styles on employees job satisfaction in Ethiopian public universities', Contemporary Management Research 13(3), 165-176. https://doi.org/10.7903/cmr.17668

Kaiser, H.F., 1974, 'An index of factorial simplicity', Psychometrika 39(1), 31-36. https://doi.org/10.1007/BF02291575

Kaplan, R.S. \& Norton, P.D., 1992, 'The balanced scorecard - Measures that drive performance', Harvard Business Review, January-February, pp. 71-79.

Kellen, V., 2003, Business performance measurement at the crossroads of strategy, decision-making, DePaul University, Chicago, IL.

Koh, L.S.C., Demirbag, M., Bayraktar, E., Tatoglu, E. \& Zaim, S., 2007, 'The impact of supply chain management practices on performance of SMEs', Industria Management \& Data Systems 107(1), 103-124. https://doi.org/10.1108/02635570 710719089

Kotler, P. \& Armstrong, G., 2011, Principles of marketing, 13th edn., Pearson Prentice Hall, Upper Saddle River, NJ.

Kuei, C.H., 2001, 'The relationship between supply chain quality management practices and organizational performance', International Journal of Quality \& Reliability Management 18(8), 864-872.

Kuhnert, K.W. \& Lewis, P., 1987, 'Transactional and transformational leadership: A constructive/developmental analysis', Academy of Management Review 12(4), A constructive/developmental analysis', Academy of
648-657. https://doi.org/10.5465/amr.1987.4306717

Laohavichien, T., Fredendall, L.D. \& Cantrell, R.S., 2009, 'The effects of transformational Journal 16(2), 7-24. https://doi.org/10.1080/10686967.2009.11918223

Leedy, P.D. \& Ormrod, J.E., 2015, Practical research, 11th edn., Pearson, Harlow Essex.

Lekhanya, L.M., Olajumoke, N.G. \& Nirmala, D., 2017, ‘Exploring fast moving consumer goods (FMCG) small, medium and micro enterprises manufacturers' need for innovation to achieve growth', Environmental Economics 8(2), 8-16. https://doi. org/10.21511/ee.08(2).2017.01

Li, G., Yang, H., Sun, L. \& Sohal, A., 2009, 'The impact of IT implementation on supply chain integration and performance', International Journal of Production Economics 120(1), 125-138. https://doi.org/10.1016/j.ijpe.2008.07.017
Lin, C., Chow, W.S., Madu, C.N., Kuei, C. \& Yu, P.P., 2005, 'A structural equation model of supply chain quality management and organizational performance', International Journal of Production Economics 96(3), 355-365. https://doi.org/ 10.1016/j.ijpe.2004.05.009

Lin, C., Kuei, C. \& Chai, K., 2013, 'Identifying critical enablers and pathways to high performance supply chain quality management', International Journal of Operations \& Production Management 33(3), 347-370.

Loury-Okoumba, W.V. \& Mafini, C., 2018, 'Buyer-supplier relationships and firm performance in the fast-moving consumer goods retail industry', Journal of Contemporary Management 15(1), 850-878.

Luthans, F., 2005, Organizational behavior, 10th edn., McGraw-Hill Irwin, Boston, MA.

Malhotra, S., 2014, 'A study on marketing fast moving consumer goods (FMCG)', International Journal of Innovative Research \& Development 3(1), 1-3.

Maxwell, J. \& Moores, E., 2007, 'The development of a short scale measuring aggressiveness and anger in competitive athletes', Psychology of Sport and Exercise 8(2), 179-193. https://doi.org/10.1016/j.psychsport.2006.03.002

Maynard, J., 2016, South African household spending patterns, viewed 27 January 2019, from https://za.investing.com/analysis/blog:-south-african-householdspending-patterns-200169037

Mercer, A.W., Kreuter, F., Keeter, S. \& Stuart, E.A., 2017, 'Theory and practice in nonprobability surveys: Parallels between causal inference and survey inference', Public Opinion Quarterly 81(1) 250-271. https://doi.org/10.1093/poq/nfw060

Mikelsone, E. \& Liela, E., 2016, 'Idea management and organisational effectiveness: A research gap', Journal of Business Management 12, 4-23.

Murray, L., Nguyen, H., Lee, Y., Remmenga, M.D. \& Smith, D.W., 2012, 'Variance inflation factors in regression models with dummy variables', Proceedings of the 2012 - 24th Annual Conference on Applied Statistics in Agriculture, Kansas State University, Kansas, April 26-May 01, 2012, pp. 161-177.

Nick, T.G., 2007, Descriptive statistics: Topics in biostatistics: Methods in molecular biology, Springer, New York.

Noko, I.L., 2018, Enterprise development and transformation in the FMCG and agriculture sector, Report by the NPI Governance Consulting, viewed 27 January 2019, from https://npiconsulting.co.za/wp-content/uploads/2018/03/NPI-BEEFMCG-ESD-Report.pdf

Norris, M. \& Lecavalier, L., 2009, 'Evaluating the use of exploratory factor analysis in developmental disability psychological research', Journal of Autism and Developmental Disorders 40(1), 8-20. https://doi.org/10.1007/s10803-009-0816-2

Nunnally, J.C., 1978, Psychometric theory, 2nd edn., McGraw-Hill, New York.

Nur, S. \& Zulkiffli, A., 2014, 'Business performance for SMEs: Subjective or objective measures?', Review of Integrative Business and Economics Research 3(1), 371-381.

Nze, G., 2015, 'Exploring fast moving consumer goods (FMCG) small, medium and micro enterprises (SMME) manufacturers need for innovation to achieve growth in KwaZulu-Natal', Master's dissertation, Durban University of Technology, Durban, South Africa, viewed 03 January 2019, from http://openscholar.dut.ac. za/bitstream/10321/1516/1/GRACE_2016.pdf

O'Brien, R., 2007, 'A caution regarding rules of thumb for variance inflation factors', Quality and Quantity 41(5), 673-690. https://doi.org/10.1007/s11135-006-9018-6

Penno, M.C., 2017, A positive theory of accounting-based management by exception (May 31, 2017), viewed 27 January 2019, from https://papers.ssrn.com/sol3/ papers.cfm?abstract_id=2978180

Rautenbach, C. \& Rothmann, S., 2017, 'Antecedents of flourishing at work in a fastmoving consumer goods company', Journal of Psychology in Africa 27(3), 227-234. https://doi.org/10.1080/14330237.2017.1321846

Robbins, S.P., Judge, T.A. \& Sanghi, S., 2007, Organizational behavior, 12th edn., Pearson, Delhi.

Schroeder, L.D., Sjoquist, D.L. \& Stephan, P.E., 2017, 'Chapter 1 linear regression', in H. Salmon, (ed.), Understanding regression analysis: An introductory guide, pp. 1-20, SAGE Publications, London.

Shange, N., 2018, 'Feeling the pinch: SA's spending habits adapt to tough economic times', Times Live, 10 August, viewed 27 January 2019, from https://www. timeslive.co.za/news/consumer-live/2018-08-10-feeling-the-pinch-sas-spendinghabits-adapt-to-tough-economic-times/

Skogstad, A., Hetland, J., Glasø, L. \& Einarsen, S., 2014, 'Is avoidant leadership a root cause of subordinate stress? Longitudinal relationships between passive-avoidant leadership and role ambiguity', Work \& Stress: An International Journal of Work Health \& Organisations 28(4), 323-341. https://doi.org/10.1080/02678373. 2014.957362

Smith, T.M. \& Reece, J.S., 1999, 'The relationship of strategy, fit, productivity, and business performance in a services setting', Journal of Operations Management 17(2), 145-161. https://doi.org/10.1016/S0272-6963(98)00037-0

Statistics South Africa, 2017, Poverty trends in South Africa: An examination of absolute poverty between 2006 and 2015, viewed 18 April 2018, from http:// www.statssa.gov.za/? $\mathrm{p}=10341$

Statistics South Africa, 2018, Gross domestic product: Fourth quarter 2017, Statistical Release P0441, viewed 26 April 2018, from http://www.statssa.gov.za/publications/ P0441/P04414thQuarter2017.pdf

Suhong, L., Ragu-Nathan, B., Ragu-Nathan, T.S. \& Rao, S.S., 2006, 'The impact of supply chain management practices on competitive advantage and organizational performance', Omega 34(2), 107-124. https://doi.org/10.1016/j.omega.2004. 08.002

Supply Chain Digest, 2010, The five challenges of today's global supply chains, viewed 28 April 2018, from http://www.scdigest.com/ASSETS/ON_TARGET/10-08-12-3. PHP? CID $=3649$ 
Székely, G.J. Rizzo, M.L. \& Bakirov, N.K., 2007, 'Measuring and testing independence by correlation of distances', Annals of Statistics 35(6), 2769-2794. https://doi.org/ by correlation of distances', Ann
$10.1214 / 009053607000000505$

Teoman, S. \& Ulengin, F., 2018, 'The impact of management leadership on quality performance throughout a supply chain: An empirical study', Total Quality
Management and Business Excellence 29(11-12), 1427-1451. https://doi.org/10. 1080/14783363.2016.1266244

Tiwari, K. \& Kumar Sharma, A., 2017, 'Transactional leadership in total quality management', International Journal of Engineering Technology Science and Research 4(3), 97-100.

Uwamahoro, A., 2018, 'Effects of supply chain integration on performance: An analysis of manufacturing firms in Rwanda', East Africa Research Papers in Business, Entrepreneurship and Management 3, 3-20, viewed 2 April 2019, from https:// ju.se/download/18.243bd3a4161b08d5c58163c6/1520578298502/EARPBEM\%202018-13\%20Uwamahoro.pdf.

Wadi, P. \& Gebhart, M., 2017, Africa's FMCG industry: Navigating between opportunity and uncertainty, London Stock Exchange Group's Companies to Inspire Africa 2017 Report, viewed 27 January 2019, from https://www.howwemadeitinafrica. com/africas-fmcg-industry-navigating-opportunity-uncertainty/58333/

Walumbwa, F.O., Wu, C. \& Orwa, B., 2008, 'Contingent reward transactional leadership, work attitudes, and organizational citizenship behavior: The role of procedural justice climate perceptions and strength', The Leadership Quarterly 19(3), 251-265. https://doi.org/10.1016/j.leaqua.2008.03.004
Willis, S., Clarke, S. \& O'Connor, E., 2017, 'Contextualizing leadership: Transformational leadership and management-by-exception-active in safety-critical contexts', Journal of Occupational and Organizational Psychology 90(3), 281-305. https://
Jondel Journal of Occupational and
doi.org/10.1111/joop.12172

Wu, K.S., Yang, L.R. \& Chiang, I.C., 2011, 'Leadership and six sigma project success: The role of member cohesiveness and resource management', Production Planning \& Control 23(9), 707-717.

Yildiz, S. \& Karakas, A., 2012, 'Defining methods and criteria for measuring business performance: A comparative research between the literature in Turkey and Foreign', Procedia - Social and Behavioral Sciences 58, 1091-1102.

Yu, Y. \& Huo, B., 2018, 'Supply chain quality integration: Relational antecedents and operational consequences', Supply Chain Management: An International Journal 23(3), 188-206.

Yukl, G., 2013, Leadership in organisations, 8th edn., Pearson Education, Harlow, Essex.

Zizlavsky, O., 2014, 'The balanced scorecard: Innovative performance measurement and management control system', Journal of Technology Management \& Innovation 9(3), 210-222.

Zulkiffli, S. \& Perera, N., 2011, 'A literature analysis on business performance for SMEs - Subjective or objective measures?', Proceedings of the 2011 SIBR Conference on Interdisciplinary Business and Economics Research, Society of Interdisciplinary Business Research, Bangkok, Thailand, June 16-18, 2011, pp. 1-9. 